Journal of Engineering Sciences, Assiut University, Vol. 37, No. 3, pp. 507-520,May 2009.

\title{
STRENGTHENING OF LOADED REINFORCED CONCRETE COLUMNS
}

\author{
SHERIF M. HELMY, MOHAMED A. TARKHAN, NASR Z. HASSAN \\ AND MOHAMED M. ZAKI \\ Civil Engineering Department, Faculty of Engineering, Helwan University, \\ Cairo,Egypt E-mail: mo_tarkhan@yahoo.com;nzenhom@yahoo.com
}

(Received February 9, 2009 Accepted March 30, 2009)

One of the most common problems encountered in reinforced concrete structures is the non-conformity of the element properties and load capacity with the design expectations. Therefore, strengthening investigations that attempt to increase the load capacity of the defected structural element have become an important topic in the field of reinforced concrete studies, specially, for reinforced concrete columns.

Recently, composite material such as fiber-reinforced polymer (FRP) started to become a good replacement for steel reinforcement for strengthening of reinforced concrete elements.

In the eighties and nineties, the researchers and the construction industry showed great interest in this field and intensive researches were performed to begin the practical use of these materials.

In this paper ten square columns of one third scale were tested and examined. These columns were loaded up to 0.3 or 0.5 of the nominal failure load. The load was kept constant at these values for about 24 hours. Columns were examined for the cracks and deformations, after that the columns were strengthened with glass fiber reinforced polymer $(G F R P)$ or carbon fiber reinforced polymer (CFRP). Finally, the load increased till failure. The ultimate loads, mode of failure and energy absorption were recorded and analyzed.

KEYWORDS: R.C. Columns, Strengthening, Pre-loading, Glass and Carbon Fiber

\section{INTRODUCTION}

Columns are compression members which transmit loads from the higher levels to the lower levels, and then to the foundations. Since columns are the most important elements of the structure, failure of one column in a critical location can cause a progressive collapse of adjoining floors and may lead to the collapse of the entire structure. In this respect, the repair and strengthening of columns are very important.

Strengthening a loaded column is very difficult in-spite of the fact that it is simulating the actual case, where in field it is impossible to remove the loads from the column during strengthening. Referring to the available studies and researches [1 to 8], it is noticed that most of the existing studies were conducted on columns which were strengthened without any pre-loading level. So, the behavior of strengthened loaded columns with fiber reinforced polymer (FRP) will be studied and may be differed than that with unloaded one. In this study, it is intended to have an experimental study of 
columns strengthened using glass fiber reinforced polymer (GFRP) or carbon fiber reinforced polymer (CFRP) under loading.

The main objectives of this work are to study the effect of strengthening of R.C. columns under loading on its loading capacity. The aim of this work has been set out in the following points:

1. Experimental study to know the effect of various types of strengthening techniques on the behavior of reinforced concrete columns.

2. Strengthening techniques using partially confinement or full confinement

3. Effect of preloading level during strengthening.

\section{EXPERIMENTAL PROGRAM}

\section{Test Specimens}

The experimental program of the current research consists of ten square reinforced concrete columns of one-third scale divided into five groups as shown and illustrated in Table (1). All columns were identical in size, (square cross section of $100 \times 100 \mathrm{~mm}$ and $850 \mathrm{~mm}$ clear height) as shown in Fig. (1). The clear concrete cover was $15 \mathrm{~mm}$. Each column was reinforced with $4 \phi 6 \mathrm{~mm}$ longitudinal reinforcing plain bars providing a reinforcement ratio of 0.012 in the longitudinal direction. For all columns, stirrups were provided of $4 \mathrm{~mm}$ plain bars. Spacing of stirrups were $20 \mathrm{~mm}$ at the column ends and $50 \mathrm{~mm}$ at the mid height. Stirrups were concentrated at the column ends to avoid local failure due to stress concentration.

The columns were connected at the top and bottom to a square slab of dimensions $250 \times 250 \times 50 \mathrm{~mm}$. The clear cover was $10 \mathrm{~mm}$. Each slab was reinforced with $4 \phi 4 \mathrm{~mm}$ top and bottom in each direction. The description of groups as follow:

Table 1: Details of Test Specimens

\begin{tabular}{|c|c|c|c|c|}
\hline $\begin{array}{c}\text { Group } \\
\text { No }\end{array}$ & $\begin{array}{c}\text { Column } \\
\text { No }\end{array}$ & $\begin{array}{c}\text { Strengthening } \\
\text { Type }\end{array}$ & $\begin{array}{c}\text { Pre-load } \\
\text { Level }\end{array}$ & $\begin{array}{c}\text { Strengthening } \\
\text { Location }\end{array}$ \\
\hline \multirow{3}{*}{ I } & CR1 & ---- & ---- & Without strengthening \\
\cline { 2 - 6 } & CR2 & ---- & ---- & Without strengthening \\
\hline \multirow{2}{*}{ II } & CG1 & GFRP & $0.3 \mathrm{P}_{\mathrm{n}}$ & Partially Confinement \\
\cline { 2 - 6 } & CG2 & GFRP & $0.3 \mathrm{P}_{\mathrm{n}}$ & Full Confinement Jacket \\
\hline \multirow{2}{*}{ III } & CG3 & GFRP & $0.5 \mathrm{P}_{\mathrm{n}}$ & Partially Confinement \\
\cline { 2 - 6 } & $\mathrm{CG} 4$ & GFRP & $0.5 \mathrm{P}_{\mathrm{n}}$ & Full Confinement Jacket \\
\hline \multirow{2}{*}{ IV } & $\mathrm{CC} 1$ & CFRP & $0.3 \mathrm{P}_{\mathrm{n}}$ & Partially Confinement \\
\cline { 2 - 6 } & $\mathrm{CC} 2$ & CFRP & $0.3 \mathrm{P}_{\mathrm{n}}$ & Full Confinement Jacket \\
\hline \multirow{3}{*}{$\mathbf{V}$} & $\mathrm{CC} 3$ & $\mathrm{CFRP}$ & $0.5 \mathrm{P}_{\mathrm{n}}$ & Partially Confinement \\
\cline { 2 - 6 } & $\mathrm{CC} 4$ & $\mathrm{CFRP}$ & $0.5 \mathrm{P}_{\mathrm{n}}$ & Full Confinement Jacket \\
\hline
\end{tabular}


Group No. I: consists of two columns designated by CR1 and CR2, they represent the behavior of the control column reference specimens to determine the failure column load capacity $\mathrm{P}_{\mathrm{n}}$ without strengthening.

Group No. II: represents the strengthening using GFRP at a load value equal to $0.3 \mathrm{P}_{\mathrm{n}}$. This group consists of two columns designated by CG1, and CG2, Fig (2-a), CG1 is strengthened with GFRP partially confinement layers along the column height specimen of $50 \mathrm{~mm}$ width and $100 \mathrm{~mm}$ spacing centerline to centerline, Fig. (2-b) CG2 was strengthened with a full confinement jacket of GFRP layers.

Group No. III: represents the strengthening using GFRP at a load value equal to 0.5 $\mathrm{P}_{\mathrm{n}}$. This group consists of two columns designated by CG3, and CG4, where CG3 is strengthened with GFRP partially confinement layers along the column height specimen of $50 \mathrm{~mm}$ width and $100 \mathrm{~mm}$ spacing centerline to centerline, while CG4 is strengthened with a full confinement jacket of GFRP layers.

Group No. IV: represents the strengthening using CFRP at a load value equal to 0.3 $\mathrm{P}_{\mathrm{n}}$. This group consists of two columns designated by $\mathrm{CC} 1$, and $\mathrm{CC} 2$, where $\mathrm{CC} 1$ is strengthened with CFRP partially confinement layers along the column height specimen of $50 \mathrm{~mm}$ width and $100 \mathrm{~mm}$ spacing centerline to centerline, while CC2 is strengthened with a full confinement jacket of CFRP layers.

Group No. V: represents the strengthening using CFRP at a load value equal to $0.5 \mathrm{P}_{\mathrm{n}}$. This group consists of two columns designated by CC3, and CC4, where CC3 is strengthened with CFRP partially confinement layers along the column height specimen of $50 \mathrm{~mm}$ width and $100 \mathrm{~mm}$ spacing centerline to centerline, while CC42 is strengthened with a full confinement jacket of CFRP layers..
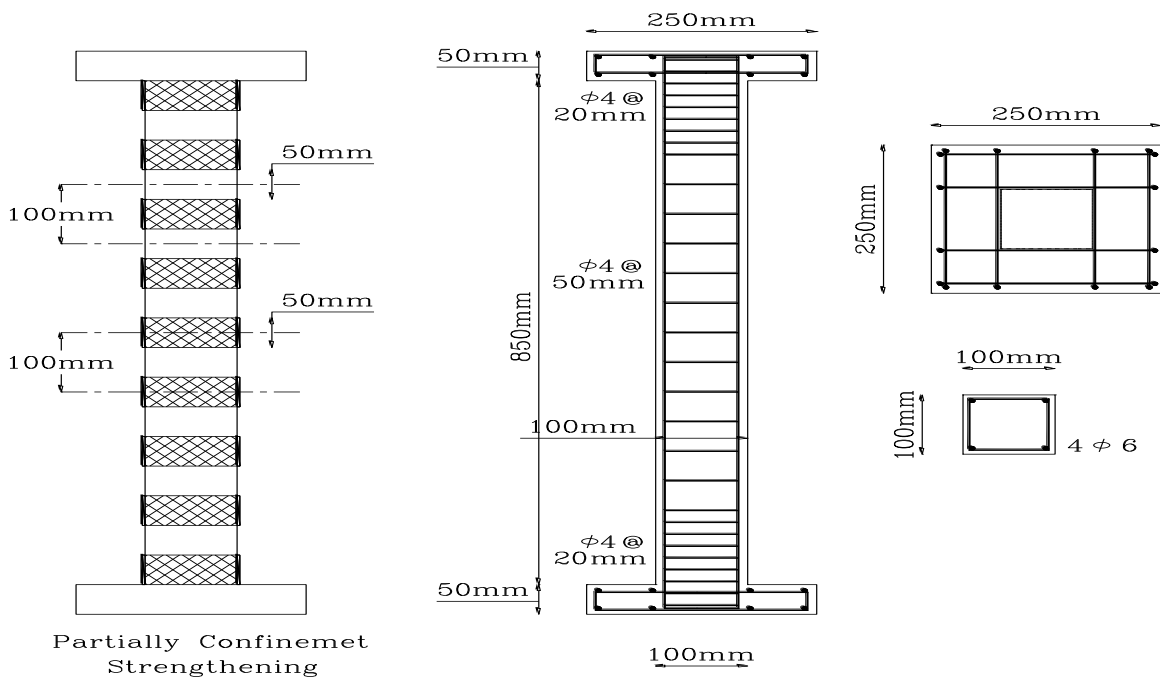

Figure 1: Details of the Tested Columns Including the Method of Confinement 


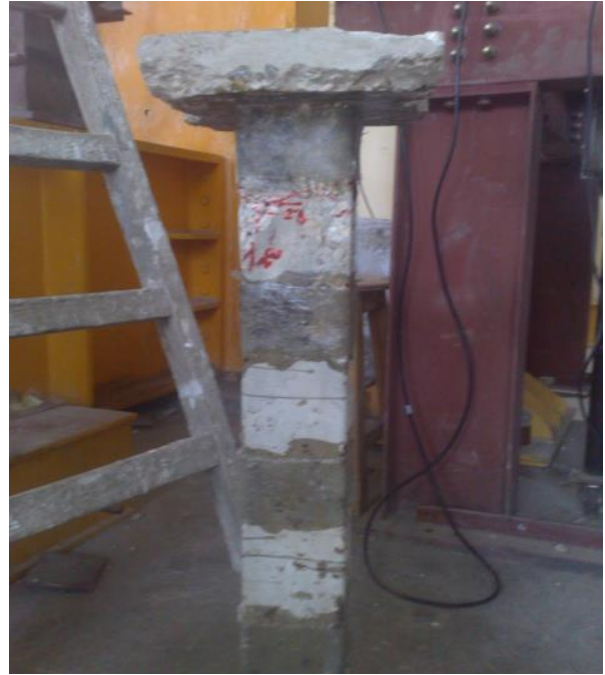

a) Partially Confinement

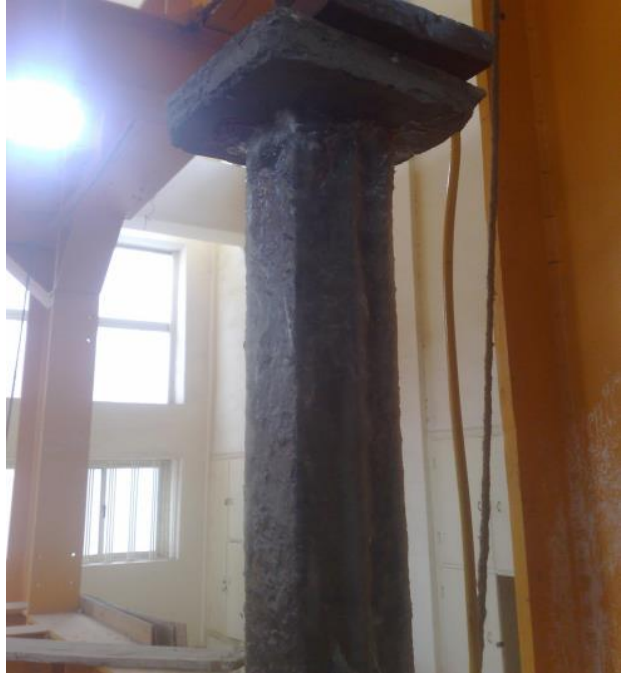

b) Full Jacket Confinement

Figure 2: Specimens of Confinement

\section{The Used Materials}

Ordinary Portland cement, fine and coarse siliceous aggregate were used in making the concrete mix. The nominal maximum size of aggregate was $15 \mathrm{~mm}$. The designed concrete mix ratio was $1: 1.83: 3.66$, the water/cement ratio was 0.55 , the cement and water content were $350 \mathrm{~kg} / \mathrm{m}^{3}$ and $200 \mathrm{lit} / \mathrm{m}^{3}$ respectively. The average characteristic compressive strength $\mathrm{F}_{\mathrm{cu}}$ is $30 \mathrm{MPa}$ after 28 days and mild steel (St. 24/35) was used for the reinforcement.

Glass Fiber Reinforced Polymer (GFRP) and Carbon Fiber Reinforced Polymer (CFRP) had been used as strengthening materials. The technical data of these materials are presented in Table (2) and Table (3) respectively.

Table 2: Technical Data for Glass Fiber Reinforced Polymer (GFRP) MBT-MBRACTM G SHEET 600

\begin{tabular}{|l|l|}
\hline Color & White \\
\hline Base & $\begin{array}{l}\text { E-Glass fiber reinforced with an } \\
\text { epoxy matrix }\end{array}$ \\
\hline Area Density & $600 \mathrm{gm} / \mathrm{m}^{2}$ (main directions) \\
\hline Effective Thickness & $0.23 \mathrm{~mm}$ \\
\hline Ultimate Deformation, ASTM D3039: & $2.8 \%$ \\
\hline Tensile Modulus of Elasticity, ASTM D3039: & $80 \mathrm{GPa}$ \\
\hline Tensile Strength, ASTM D3039: & $1700 \mathrm{MPa}$ \\
\hline Tensile Strength per mm width, & $390 \mathrm{~N} . \mathrm{mm}-1$ \\
\hline
\end{tabular}


Table 3: Technical Data for Carbon Fiber Reinforced Polymer (CFRP)

Sikawrap Hex® Fabric Type 230C.

\begin{tabular}{|l|l|}
\hline Color & Black \\
\hline Base & Carbon fiber reinforced with an epoxy matrix \\
\hline Areal Weight & $220 \mathrm{~g} / \mathrm{m}^{2} \pm 10 \mathrm{~g} / \mathrm{m}^{2}$ \\
\hline Density & $1.78 \mathrm{~g} / \mathrm{m}^{3}$ \\
\hline Fabric Design Thickness & $0.12 \mathrm{~mm}$ \\
\hline Tensile Strength of Fibers & $4100 \mathrm{~N} / \mathrm{mm}^{2}$ \\
\hline Tensile E-modulus of Fiber & $231000 \mathrm{~N} / \mathrm{mm}^{2}$ \\
\hline Strain at Break of Fibers & $1.7 \%$ \\
\hline
\end{tabular}

\section{Test Setup}

The specimens were fixed to a main frame machine with a hydraulic cell of 100 ton capacity. Load was applied on the tested column gradually up to failure. Both the load and corresponding shortening were recorded. Fig.(3) shows the test setup instruments.

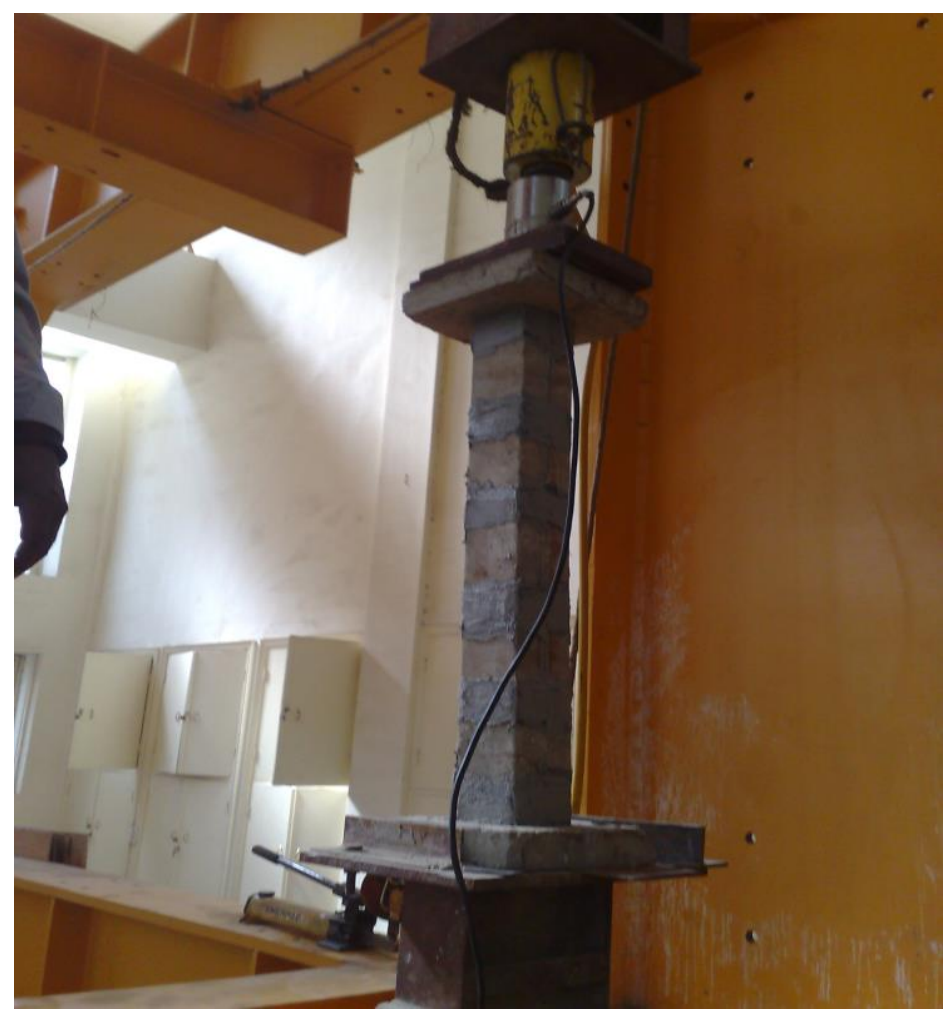

Figure 3: Test Setup 


\section{Applied Loads and Column Strengthening}

The columns in group (II) to group $(\mathrm{V})$ were loaded gradually up to $0.3 \mathrm{P}_{\mathrm{n}}$ or $0.5 \mathrm{P}_{\mathrm{n}}$. After that the load cell was stopped at the pre-loaded level and the columns were inspected to record cracks or other failure specimen. The columns were strengthened according to the following steps under loading:

1- The column surface and edges were prepared by grinding, followed by compressed air to remove all loose particles and dust.

2- For CFRP, the resin matrix was prepared by mixing the resin and hardener. (Sikadur 330).

3- For GFRP, the resin matrix was prepared by mixing of (sikadur-31) and (quartz sand-501) mix ratio 1:1 parts by weight.

4- The resin was applied first to the column surface using a paint brush, taking care to fill in all voids.

5- The GFRP or CFRP wrap was applied through one circumference, pressing firmly down with a rag until the resin was applied.

6- In all cases, the outside layer was extended by an overlap of $100 \mathrm{~mm}$ to ensure the development of full composite strength.

7- After the epoxy resin had been hardened (after 24 hours) the loads was increased gradually.

\section{Measurements}

Vertical strains, crack propagation and the mode of failure were recorded.

\section{EXPERIMENTAL RESULTS}

The control two columns specimens of CR1 and CR2 in Group (I) were loaded gradually up to failure to determine the nominal load. The two control columns specimens had same failure load.

\section{Load-Shortening Relationship of Strengthening Columns}

Figure (4) and (5) show the load-shortening relationship for each group separately compared with the reference column CR2, while Figure (6) and (7) represent the failure load and final displacement respectively for all tested columns compared to the reference column CR2. When the column was loaded the shortening is increased up to about $1 \mathrm{~mm}$ due to the compaction of the upper slab surface connected to the column. After that the shortening and load were proportionally increased up to failure. The curves show that stiffness is increased by strengthening. In case of full confinement the increase is more than in that case of partial confinement. The columns strengthened by strips showed a small increase on the load capacity of these specimens to the control specimen. Also, columns strengthened with CFRP showed higher failure loads and more ductility at failure than that strengthened with GFRP. The strengthened columns at $0.3 \mathrm{P}_{\mathrm{n}}$ show more load capacity and displacement than that strengthened at $0.5 \mathrm{P}_{\mathrm{n}}$. 


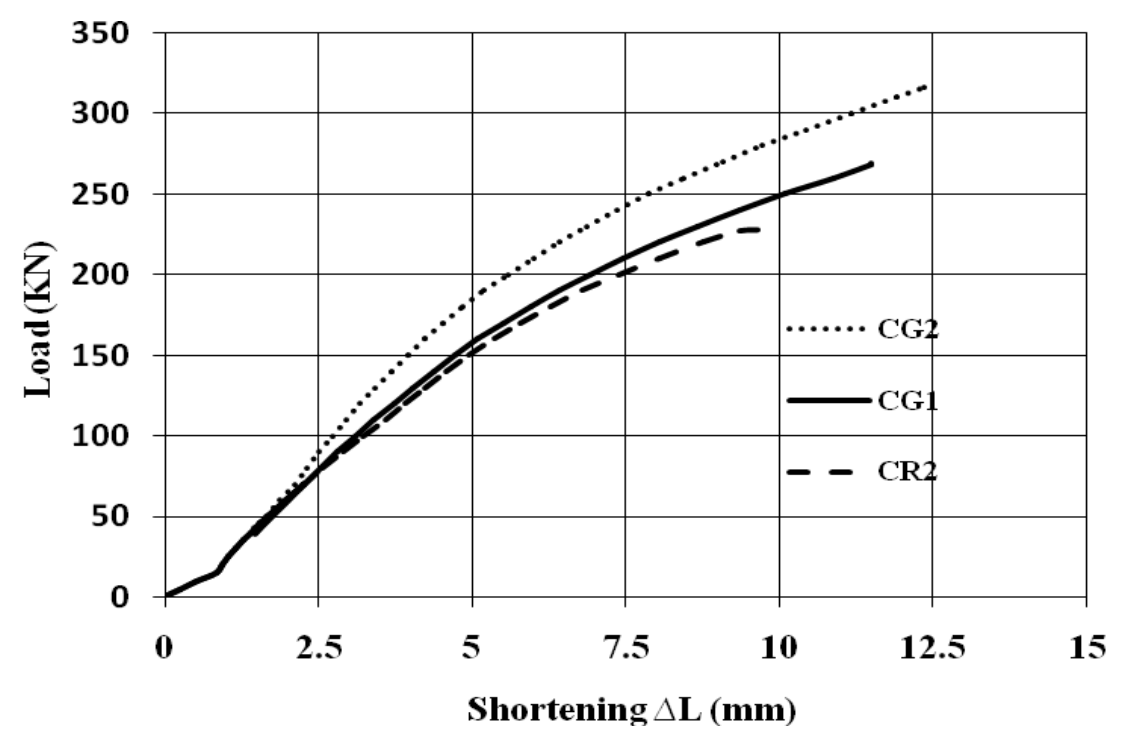

a) At $0.3 P_{n}$

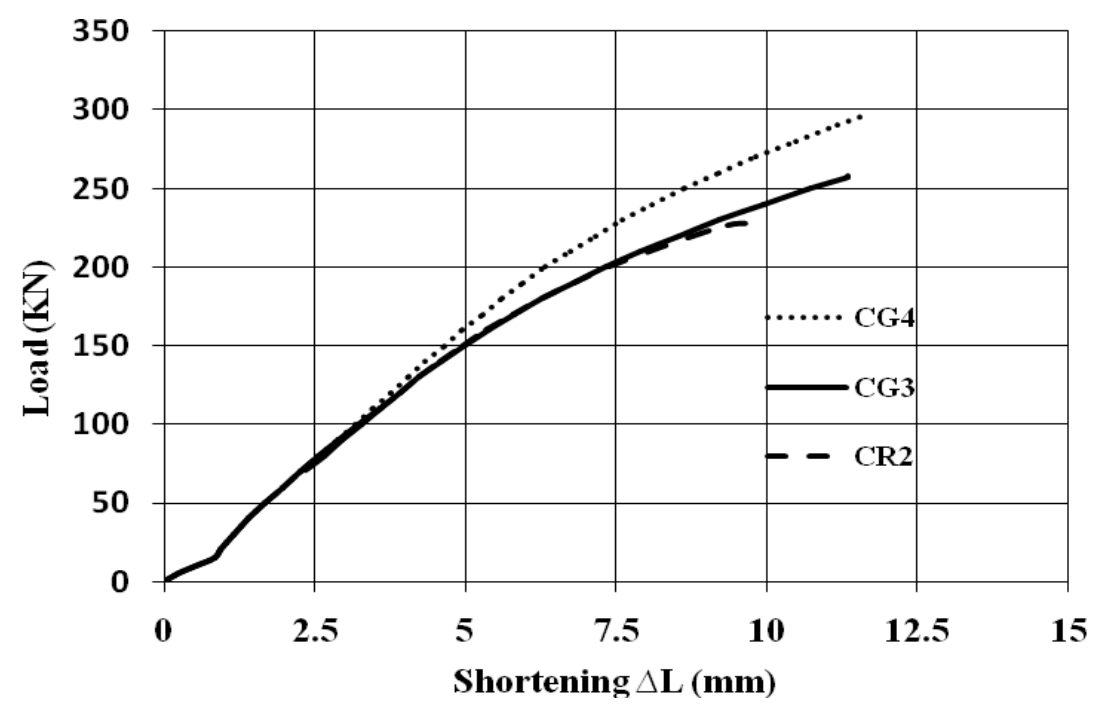

b) At $0.5 P_{n}$

Figure 4: Load Shortening Curve for Columns Strengthened using GFRP 


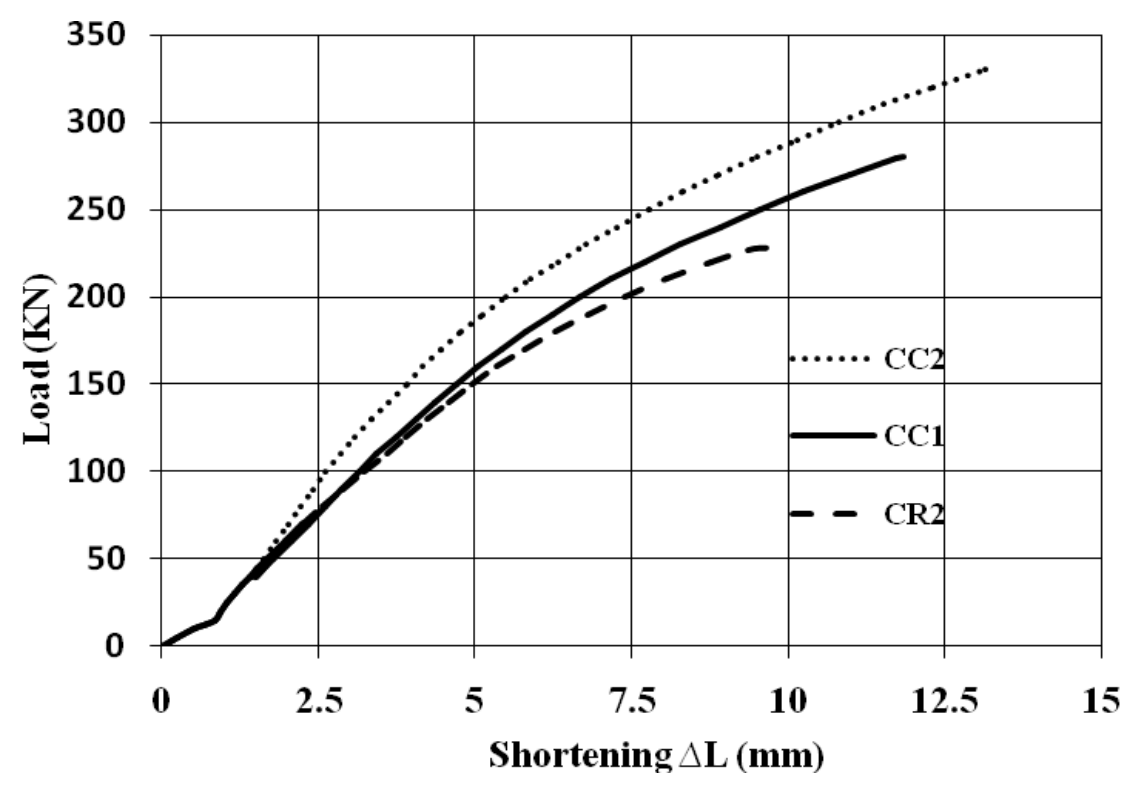

a) At $0.3 P_{n}$

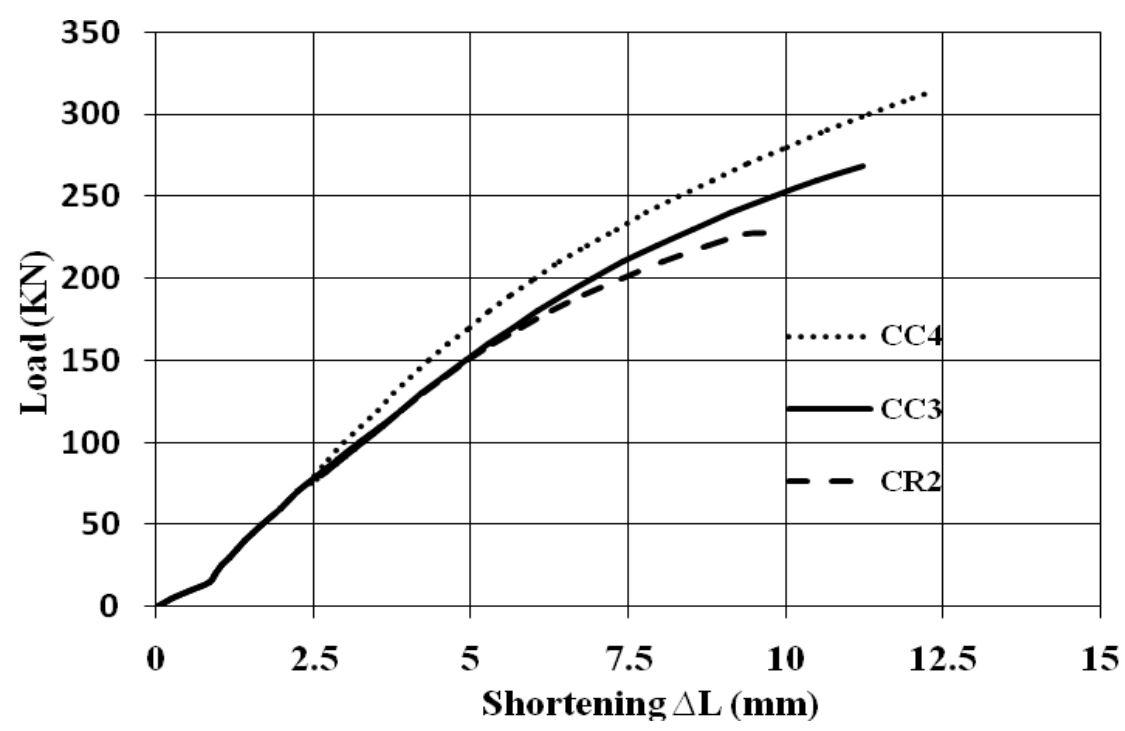

b) At $0.5 P_{n}$

Figure 5: Load Shortening Curve for Columns Strengthened using CFRP 


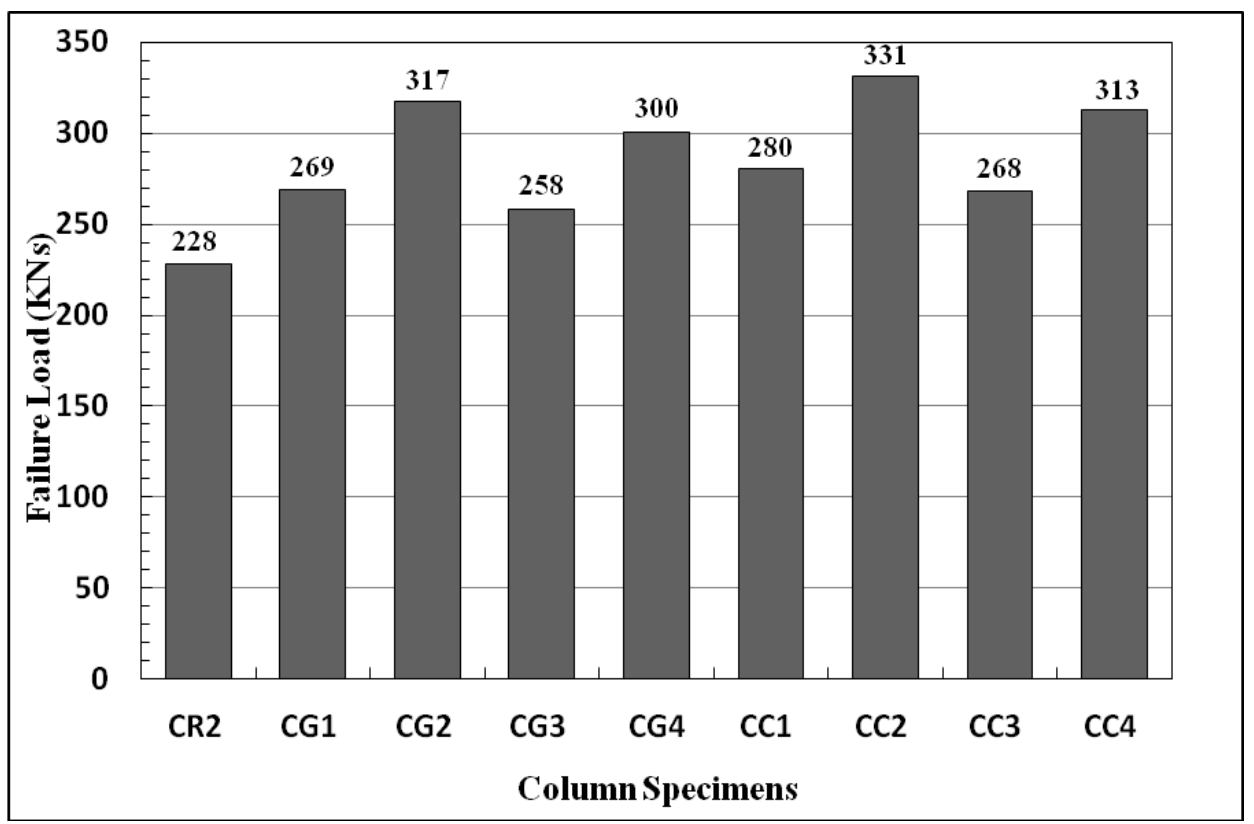

Figure 6: Failure Load of Strengthened Columns

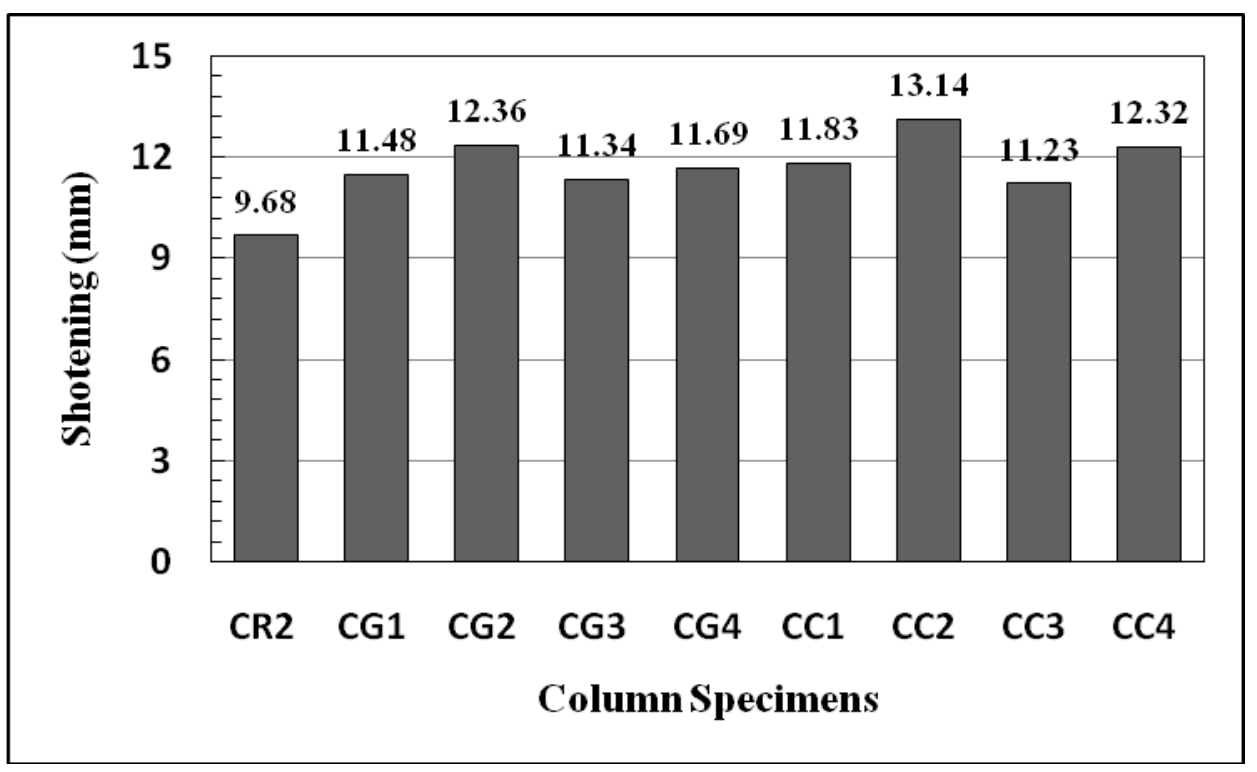

Figure 7: Final Shortening of Strengthened Columns

\section{Crack Pattern}

Crack pattern of tested specimen CG1 and CG2 are shown in Fig. (8).The crack pattern of CG1 describes the progress of cracks with loading after strengthening up to failure. 
Micro cracks started near the top third of the column and propagated vertically. The first crack initiated and could be seen at a load of $49 \%$ of the nominal failure load obtained from the control column. More longitudinal cracks appeared at a load of $99 \%$ of the nominal failure load obtained from the control column. With further loading, spalling of the concrete cover started and propagated till a complete collapse occurred at a load of $118 \%$ of the failure load obtained from the control column CR1 or CR2. Another crack pattern of column strengthened using carbon fiber is shown in Fig. (9). The final value of failure load for each column shown in Table (4) as a ratio of the nominal load obtained from the control column CR1 or CR2.

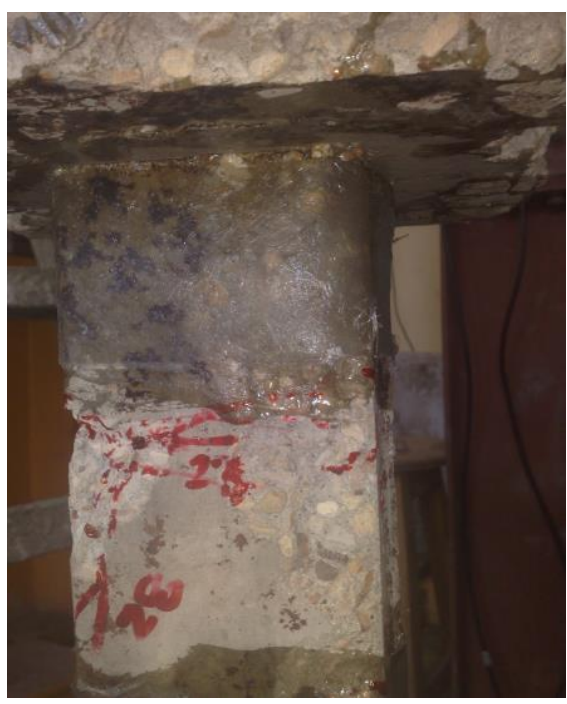

a) Column CG1

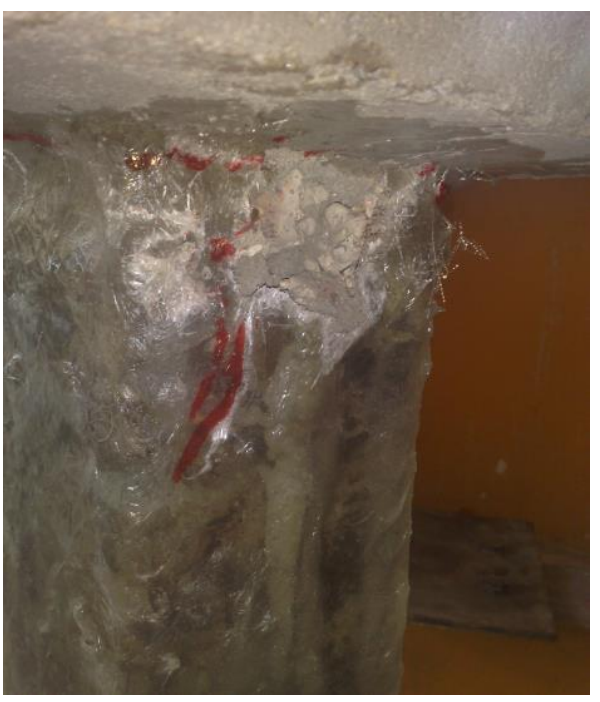

b) Column CG2

Figure 8: Crack Pattern for Column Strengthened Using GFRP

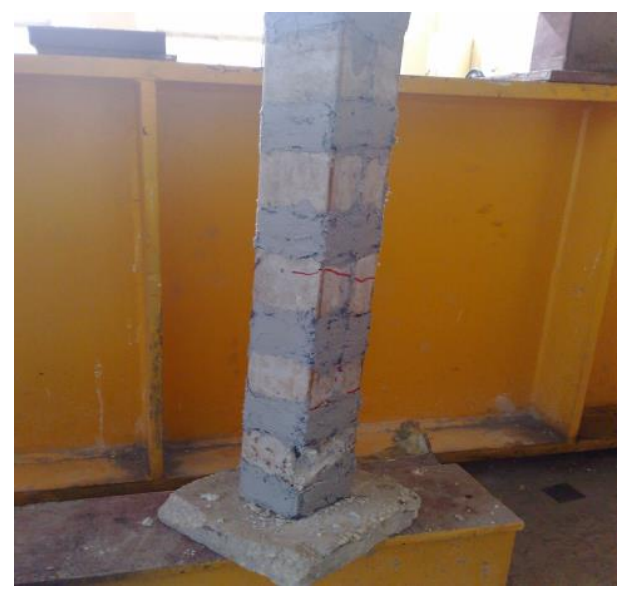

a) Column CC1

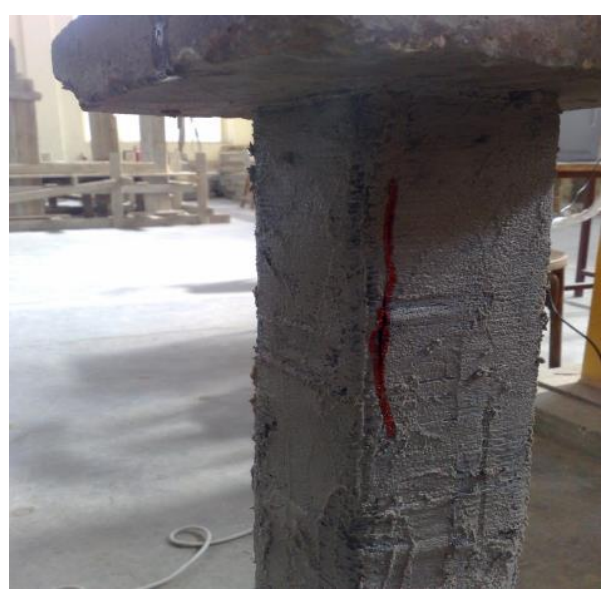

b) Column CC2

Figure 9: Crack Pattern for Column Strengthened Using CFRP 
Table 4: Results of Strengthened Columns

\begin{tabular}{|c|c|c|c|c|c|c|}
\hline $\begin{array}{c}\text { Group } \\
\text { No }\end{array}$ & $\begin{array}{c}\text { Column } \\
\text { No }\end{array}$ & $\begin{array}{c}\text { Strengthening } \\
\text { Type }\end{array}$ & $\begin{array}{c}\text { Pre-load } \\
\text { Level }\end{array}$ & $\begin{array}{c}\mathbf{P}_{\mathbf{f}} / \mathbf{P}_{\mathbf{n}} \\
\%\end{array}$ & $\begin{array}{c}\left(\Delta_{\mathbf{f}} / \Delta_{\mathbf{n}}\right) \\
\%\end{array}$ & $\begin{array}{c}\text { Energy } \\
\text { Absorption } \\
\text { KN. } \mathbf{~ m m}\end{array}$ \\
\hline \multirow{3}{*}{$\mathbf{I}$} & CR1 & ---- & --- & 100 & 100 & 911.76 \\
\cline { 2 - 7 } & CR2 & ---- & ---- & 100 & 100 & 911.76 \\
\hline \multirow{2}{*}{ II } & CG1 & GFRP-Partiallly & $0.3 \mathrm{P}_{\mathrm{n}}$ & 117.98 & 118.60 & 1276.25 \\
\cline { 2 - 7 } & CG2 & GFRP-Full & $0.3 \mathrm{P}_{\mathrm{n}}$ & 139.04 & 127.69 & 1567.50 \\
\hline \multirow{2}{*}{ III } & CG3 & GFRP-Partially & $0.5 \mathrm{P}_{\mathrm{n}}$ & 113.16 & 117.15 & 1247.35 \\
\cline { 2 - 7 } & CG4 & GFRP-Full & $0.5 \mathrm{P}_{\mathrm{n}}$ & 131.58 & 120.76 & 1483.82 \\
\hline \multirow{2}{*}{ IV } & CC1 & CFRP-Partially & $0.3 \mathrm{P}_{\mathrm{n}}$ & 122.81 & 117.14 & 1368.15 \\
\cline { 2 - 7 } & CC2 & CFRP-Full & $0.3 \mathrm{P}_{\mathrm{n}}$ & 145.18 & 135.74 & 1713.12 \\
\hline \multirow{2}{*}{$\mathbf{V}$} & CC3 & CFRP-Partially & $0.5 \mathrm{P}_{\mathrm{n}}$ & 117.54 & 116.01 & 1268.96 \\
\cline { 2 - 7 } & CC4 & CFRP-Full & $0.5 \mathrm{P}_{\mathrm{n}}$ & 137.28 & 127.27 & 1607.79 \\
\hline
\end{tabular}

Where: $\mathbf{P}_{\mathbf{f}}$ is the failure load of each column after strengthening for groups II, III, IV and $\mathrm{V}$.

$\mathbf{P}_{\mathbf{n}} \quad$ is the failure load of control columns group I.

$\Delta_{\mathbf{f}} \quad$ is the final shortening of each column after strengthening for groups II, III, IV and V.

$\Delta_{\mathbf{n}} \quad$ is the final shortening control columns group I.

\section{Energy Absorption of Strengthened Columns}

Figure (10) shows the energy absorption of all tested columns compared to the reference column CR2. The energy absorption is higher in case of column strengthening by CFRP than that strengthened by GFRP for the same pre-loading level. When the pre-loading level is increased, the energy absorption is decreased. Also, the full confinement shows higher energy absorption than that of strips confinement.

\section{CONCLUSIONS}

1- Strengthening using CFRP wraps results in the best enhancements in load capacity, Ductility and energy absorption, but by considering the lower cost of glass fiber, it can be said that it gives good results for strengthening. 


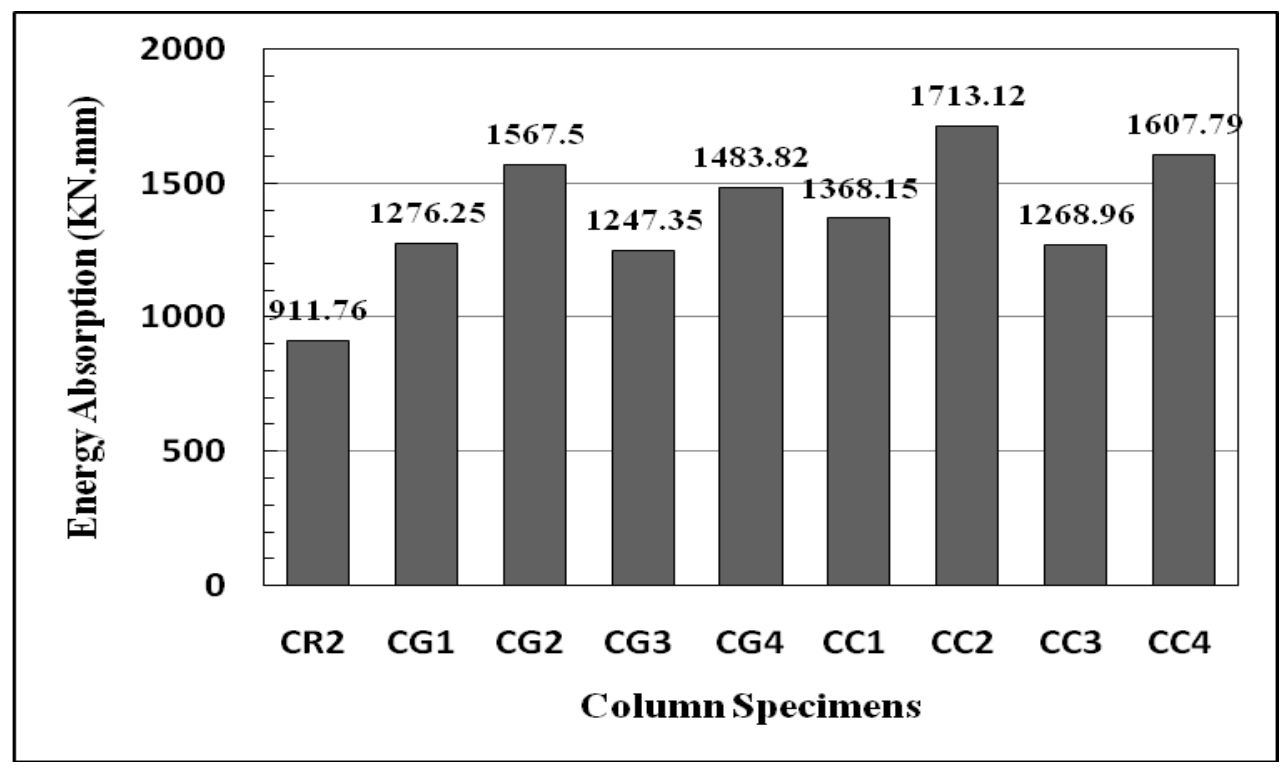

Figure 10: Energy Absorption of Strengthened Columns

2- The average increase in failure load for columns strengthened by GFRP With respect to the reference column were $18 \%$ to $39 \%$, while these values in case of columns strengthened by CFRP were $23 \%$ to $45 \%$.

3- The relative enhancement of load capacity resulted by using full jacket instead of partially strengthening by strips is not directly proportional to the difference in strengthening zone, material volume and cost. It is clear that increasing in strengthening zone never means duplicating the gain in load capacity.

4- The comparison between full confined jacket specimens by CFRP, CC1 (at $0.3 \mathrm{P}_{\mathrm{n}}$ ) and CC3 (at $0.5 \mathrm{P}_{\mathrm{n}}$ ) showed that the percentage decrease in load capacity is lower than the percentage increase in pre-load level. This means that strengthening becomes more effective as the CFRP strengthened at low pre-load level.

5- The highest value of energy absorption and more ductility value were in the case of strengthening by CFRP jacket

\section{REFERENCES}

1- El-Afandy, T. H. (2002): Strengthening of Reinforced Concrete Columns Using Advanced Laminates, Thesis for M.Sc. Degree, Ain Shams University.

2- Masia, Mark J., Gale, Trevor N., and Shrive, Nigel G. (2004): Size Effects In Axially Loaded Square- Section Concrete Prisms Strengthened Using Carbon Fiber Reinforced Polymer Wrapping. NRC Canada, Can. J. Civ. Eng.31 pp 1-13.

3- Mohammed, A.R. (2001): Improving the Performance of Reinforced Concrete Elements Using Fiber- Reinforced Plastics, M. Sc. Thesis, Ain Shams University. 
4- Naguib, W., and Mirmiran, A. (2002): Time-Dependent Behavior of Reinforced of Fiber-Reinforced polymer-Confined Concrete Columns under Axial Loads. ACI Structural Journal, V. 99, No. 2, Mar. - Apr., pp. 142-148.

5- Pantelides, P., and Yan, Zihan (2007): Confinement model of Concrete with Externally Bonded FRP Jackets or Post-tensioned FRP shells. Journal of Structural Engineering ASCE, September 2007, 1288.

6- Parvin, A., and and Jamwal, A. (2005): Performance of Externally FRP Reinforced Concrete Columns for Changes in Angle of the Wrap and Concrete Strength. Department of Civil Engineering, University of Toledo, OH 43606 - 3390, April, USA.

7- Wang, Y. C., and Restrepo, J. I. (2001): Investigation of Concentrically Loaded Reinforced Concrete Columns Confined with Glass Fiber Reinforced Polymer Jackets. ACI Structural Journal, V. 98, No. 3, May- June, pp. 377- 385.

8- Toutanji, H. (1999): Stress - Strain Characteristics of Concrete Columns Externally Confined with Advanced Fiber Composite. ACI Materials Journal, June, Title no. 97 - M50.

\section{تلاعيم الأعمدة الخرسانية المسلحة المحملة}

تقوية الأعمدة الخرسانية المسلحة تحظي باهتمام كبير من الباحثين نظرا لأهميتها وخطورتها عند الإنهيار • ومن أساليب تقوية هذه الأعمدة عمل قميص من الألياف الزجاجية أو الألياف الكربونية لسهولة

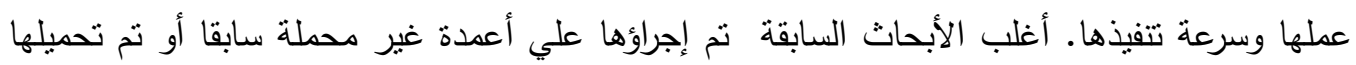

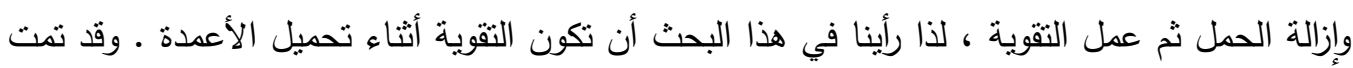
الدراسة في ظل المتغيرات الآتية:

1- نوع مادة التقوية: تم استخدام الألياف الزجاجية في تقوية أربع أعمدة و الألياف الكربونية في

$$
\text { تقوية أربع أعمدة أخري. }
$$

2- أسلوب التقوية: لكل نوع من الألياف تم تقوية عمودين باستخدام شرائح من الألياف بعرض 5

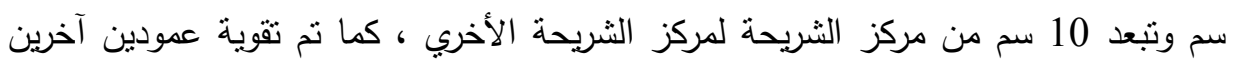
باستخدام قميص كامل من الألياف حول العمود.

3- التحميل السابق أثناء التقوية: لكل إسلوب من أساليب التقوية نم تقوية عمودين عند حمل سابق يعادل 30\% من حمل الإنهيار لعينة التحكم ، وعمودين آخرين عند حمل سابق يعادل 50 من حمل الإنهيار لعينة التحكم .

ولدراسة المتغيرات السابقة تم في هذا البحث إختبار ودراسة عدد 10 أعمدة من الخرسانة المسلحة بأبعاد

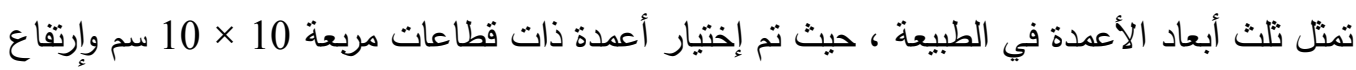
صافي 90 سم ، قسمت هذه الأعدة إلي خمس مجموعات ، المجموعة الأولي هي مجموعة التحكم 
بدون تقوية وقد حملت بحمل حتي الإنهيار لتحديد حمل إنهيار العمود والذي علي أساسه تم تقوية

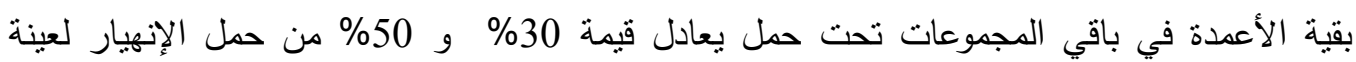
التحكم ، بعد ذلك تم تكملة تحميل الأعمدة بعد تقويتها حتي الوصول إلي درجة الإنهيار ـ تم تحليل

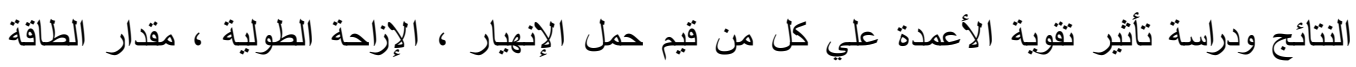
الممنصة من العمود ـ وقد أدت الدراسة إلي النتائج الآتية:

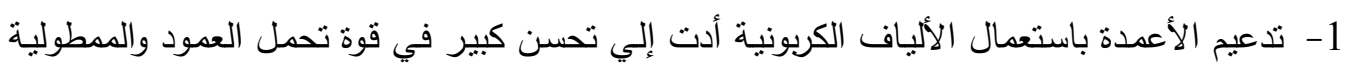

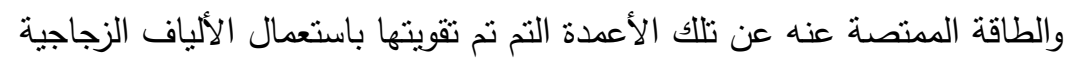

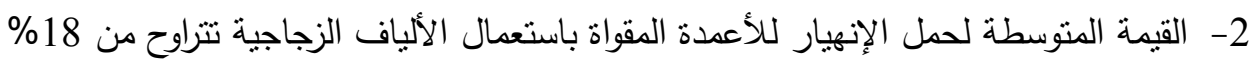

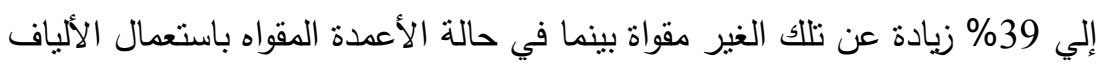

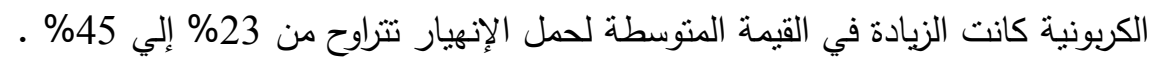
3- الأعمدة المقواة بقيص كامل أفضل كثيرا عن تلك المقواة باستخدام شرائح علما بأن القيمة النسبية

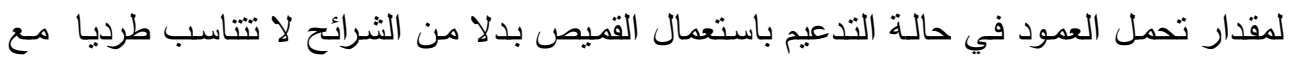

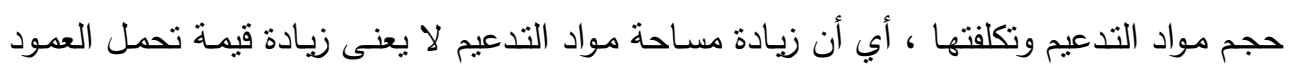
بنفس النسبة. 4- المقارنة بين التدعيم باستخدام قميص من الألياف الكربونية محمل بحمل بعادل 30\% و 50\%

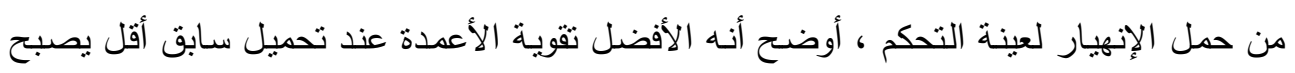
أكثر فائدة عن تلك التي نت تقويتها عند مستوي تحميل أكبر .

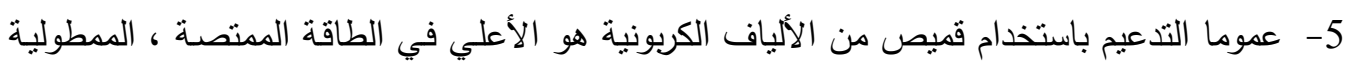

